\title{
ANALISIS PENERAPAN KEWIRAUSAHAAN KORPORASI PADA UKM DI KABUPATEN TANA TORAJA
}

\section{Penulis}

\section{Raba Nathaniel}

Fakultas Ekonomi

Universitas Andi Djemma

Email: raba@gmail.com

\section{Info Artikel}

p-ISSN : 2615-1871

e-ISSN : 2615-5850

Volume 2 Nomor 1, Maret 2019

Received 13th November 2018 / Accepted 4th February 2019

\begin{abstract}
ABSTRAK
Tujuan penelitian untuk mengetahui sejauhmana penerapan kewirausahaan korporasi pada UKM di Kabupaten Tana Toraja. Hasil penelitian menunjukkan bahwa pelaku UKM di Kabupaten Tana Toraja sudah menerapkan konsep kewirausahaan korporasi dengan memadai, namun masih lemah pada inovasi, kesediaan menanggung resiko juga masih rendah, tetapi sikap proaktif sudah lebih baik.
\end{abstract}

Kata Kunci: Kewirausahaan Korporasi, Inovasi, Proaktif dan Keberanian Menanggung Resiko

\section{PENDAHULUAN}

Usaha Kecil dan Menengah (UKM) di negara berkembang seperti di Indonesia, sering dikaitkan dengan masalah-masalah ekonomi dan sosial dalam negeri seperti tingginya tingkat kemiskinan, besarnya jumlah pengangguran, ketimpangan distribusi pendapatan, proses pembangunan yang tidak merata antara daerah perkotaan dan perdesaan, serta masalah urbanisasi. Keberadaan UKM diharapkan dapat memberikan kontribusi positif yang signifikan terhadap upaya-upaya penanggulangan masalahmasalah tersebut di atas. Tingkat perkembangan bisnis UKM di Kabupaten Tana Toraja dalam lima tahun terakhir bila dilihat dari jumlah unit usaha, jumlah penyerapan tenaga kerja, nilai investasi dan nilai produksi mengalami peningkatan yang kurang menggembirakan.

Penerapan konsep kewirausahaan korporasi masih sangat lemah dilakukan oleh para pelaku UKM di Kabupaten Tana Toraja, dengan alasan ingin mempertahankan keaslian dan keunikan beberapa produk lokal yang ada di Tana Toraja, sehingga penerapan teknologi canggih belum mendapat perhatian serius oleh para pelaku UKM, kecuali untuk produk-produk yang lain seperti, industri just markisa dan industri penggilingan kopi. Dampak lain dari belum berkembangnya UKM secara memadai karena lesunya kunjungan wisatawan ke Tana Toraja sebagai salah satu faktor yang mendukung berkembangnya UKM. Kurangnya kunjungan wisatawan mengakibatkan juga menurunnya volume penjualan yang berdampak langsung pada menurunnya 
pendapatan UKM, sebab sebagian besar wisatawan membeli produk UKM di Kabupaten Tana Toraja. Dalam lima tahun terakhir ini pemerintah telah melakukan berbagai program untuk memperkuat UKM, namun fakta dilapangan menunjukkan bahwa belum semua program berjalan efektif. Berikut ini peneliti memaparkan perkembangan usaha kecil dan menengah di Kabupaten Tana Toraja pada Tabel 1 berikut ini:

Tabel 1 Perkembangan Usaha Kecil dan Usaha Menengah Kabupaten Tana Toraja Tahun $2013-2017$

\begin{tabular}{|c|c|c|c|c|c|c|}
\hline No & $\begin{array}{c}\text { Indakator } \\
\text { UKM }\end{array}$ & 2013 & 2014 & 2015 & 2016 & 2017 \\
\hline 1 & $\begin{array}{l}\text { Jumlah unit } \\
\text { usaha }\end{array}$ & $\begin{array}{r}409 \\
- \\
\end{array}$ & $\begin{array}{r}465 \\
(12,04 \%) \\
\end{array}$ & $\begin{array}{r}498 \\
(6,62 \%) \\
\end{array}$ & $\begin{array}{r}512 \\
(2,73 \%) \\
\end{array}$ & $\begin{array}{r}536 \\
(4,48 \%) \\
\end{array}$ \\
\hline 2 & $\begin{array}{l}\text { Penyerapan } \\
\text { Tenaga Kerja }\end{array}$ & $\begin{array}{r}1.227 \\
-\end{array}$ & $\begin{array}{r}1.395 \\
(12,04 \%) \\
\end{array}$ & $\begin{array}{r}1.494 \\
(6,62 \%) \\
\end{array}$ & $\begin{array}{r}1.536 \\
(2,73 \%) \\
\end{array}$ & $\begin{array}{r}1.805 \\
(14,90 \%) \\
\end{array}$ \\
\hline 3 & $\begin{array}{l}\text { Nilai } \\
\text { Investasi }\end{array}$ & $\begin{array}{r}66.621 .000 \\
-\end{array}$ & $\begin{array}{r}71.085 .000 \\
(6,28 \%)\end{array}$ & $\begin{array}{r}78.445 .000 \\
(9,38 \%)\end{array}$ & $\begin{array}{r}97.512 .000 \\
(19,55 \%)\end{array}$ & $\begin{array}{r}103.179 .000 \\
(5,49 \%)\end{array}$ \\
\hline 4 & $\begin{array}{l}\text { Nilai } \\
\text { Produksi } \\
\text { (dalamrupiah) }\end{array}$ & $\begin{array}{r}689.000 \\
-\end{array}$ & $\begin{array}{r}773.000 \\
(10,86 \%)\end{array}$ & $\begin{array}{l}821.000 \\
(5,84 \%)\end{array}$ & $\begin{array}{l}864.000 \\
(4,98 \%)\end{array}$ & $\begin{array}{r}980.000 \\
(11,84 \%)\end{array}$ \\
\hline
\end{tabular}

Sumber : Dinas Koperasi dan UMKM dan Dinas Perindustrian dan Perdagangan Kabupaten Tana Toraja, 2017

Sampai akhir tahun 2017 jumlah UKM di Kabupaten Tana Toraja sebanyak 536 unit, atau 43,68 persen dari total jumlah pelaku usaha di Kabupaten Tana Toraja. UKM di Kabupaten Tana Toraja memberi kontribusi terhadap penyerapan tenaga kerja sebanyak 1.805 orang dari jumlah angkatan kerja sebanyak 126.148 orang (Kantor Dinas Koperasi dan UMKM Kabupaten Tana Toraja, 2017). Dengan adanya sektor UKM, pengangguran akibat angkatan kerja yang tidak terserap dalam dunia kerja menjadi berkurang. Sektor UKM pun telah terbukti menjadi pilar perekonomian yang tangguh. Penelitian ini bertujuan untuk menganalisis sejauhmana penerapan kewirausahaan korporasi pada UKM di Kabupaten Tana Toraja.

\section{TINJAUAN PUSTAKA}

\section{Konsep Kewirausahaan}

Menurut Thomas W.Zimmerer (1996), kewirausahaan adalah hasil dari suatu disiplin, proses sistematis penerapan kreativitas dan inovasi dalam memenuhi kebutuhan dan peluang di pasar. Sedangkan menurut Peter F. Drucker (1994) kewirausahaan adalah suatu kemampuan untuk menciptakan sesuatu yang baru dan berbeda. Berdasarkan definisi tersebut di atas disimpulkan bahwa kewirausahaan adalah penerapan kreatifitas dan inovasi untuk memecahkan masalah dan upaya untuk memanfaatkan peluang yang dihadapi setiap hari

\section{Konsep Kewirausahaan Korporasi}

Kewirausahaan korporasi (Corporate Entrepreneurship), merupakan perilaku kewirausahaan di dalam organisasi oleh seluruh karyawan dan pimpinan untuk menghasilkan kinerja bisnis terbaik (Hisrich, Peters dan Shepherd,2008). Semangat dari kewirausahaan korporasi dalam perusahaan dimaksudkan untuk membiasakan sikap dan 
perilaku setiap individu dan kelompok di dalam perusahaan agar berusaha dan berorientasi pada penciptaan proses bisnis yang benar dan sehat melalui pengelolaan bisnis yang dapat menghasilkan kinerja bisnis yang terbaik.

Konsep Kewirausahaan Korporasi terdiri atas tiga dimensi, yaitu Inovasi, Proaktif dan Berani Menanggung Resiko:

\section{Inovasi}

Menurut Peter Drucker (2003), inovasi adalah kemampuan untuk menerapkan kreatifitas dalam rangka pemecahan masalah dan menemukan peluang (doing new thing), inovasi merupakan fungsi utama dalam proses kewirausahaan. Inovasi memiliki fungsi yang khas bagi wirausahawan. Dengan inovasi wirausahawan menciptakan baik sumberdaya produksi baru maupun pengelolahan sumber daya yang ada dengan peningkatan nilai potensi untuk menciptakan sesuatu yang tidak ada menjadi ada.

\section{Proaktif}

Menurut Lumpkin \& Dess (2003) proaktif dalam konteks kewirausahaan berkaitan dengan perspektif untuk melihat ke depan dan cenderung untuk mengambil inisiatif dengan mengantisipasi dan mengejar peluang baru dan berpartisipasi dalam merebut pasar. Definisi dari proaktif dalam kewirausahaan yaitu tindakan dalam antisipasi masalah-masalah masa depan, kebutuhan-kebutuhan, atau kesempatankesempatan. Berdasarkan definisi tersebut sikap proaktif adalah sangat penting sekali pada kewirausahaan korporasi sebab memberikan perspektif cara pandang kedepan yang menyertai aktivitas inovatif atau peluang baru.

\section{Keberanian menanggung Resiko}

Menurut Meredith (1996), ada dua alternatif atau lebih yang harus dipilih, yaitu alternatif yang mengandung risiko dan alternatif yang konservatif. Pilihan terhadap risiko ini sangat tergantung pada:

a. Daya tarik pada setiap alternatif

b. Kesediaan untuk rugi

c. Kemungkinan relatif untuk sukses atau gagal

\section{METODE PENELITIAN}

Dalam penelitian ini analisis data yang digunakan adalah Analisis Deskriptif, yaitu untuk membahas dan menndeskripsikan hasil pengolahan data tentang penerapan kewirausahaan korporasi oleh pelaku UKM di Kabupaten Tana Toraja. Adapun populasi dalam penelitian ini adalah semua unit usaha UKM yang ada di Kabupaten Tana Toraja, seperti pada Tabel 2.

Tabel 2 Gambaran Sebaran UKM Per Kecamatan Di Kabupaten Tana Toraja Tahun 2017

\begin{tabular}{clccc}
\hline \multirow{2}{*}{ No. } & \multirow{2}{*}{ Kecamatan } & \multicolumn{3}{c}{ Bentuk Usaha } \\
\cline { 3 - 5 } & & Kecil & Menengah & Total \\
\hline 1 & Makale & 256 & 49 & $\mathbf{3 0 5}$ \\
\hline 2 & Makale Utara & 40 & 5 & $\mathbf{4 5}$ \\
\hline 3 & Makale Selatan & 6 & 1 & $\mathbf{7}$ \\
\hline 4 & Sangalla' & 13 & - & $\mathbf{1 3}$ \\
\hline 5 & Sangalla' Utara & 12 & - & $\mathbf{1 2}$ \\
\hline 6 & Sangalla' Selatan & 9 & - & $\mathbf{9}$ \\
\hline 7 & Mengkendek & 41 & 6 & $\mathbf{4 7}$ \\
\hline 8 & Gandang Batu Sillanan & 28 & - & $\mathbf{2 8}$ \\
\hline 9 & Rantetayo & 18 & 2 & $\mathbf{2 0}$ \\
\hline
\end{tabular}




\begin{tabular}{llccc}
\hline 10 & Kurra & 4 & - & $\mathbf{4}$ \\
\hline 11 & Rembon & 12 & - & $\mathbf{1 2}$ \\
\hline 12 & Masanda & - & - & - \\
\hline 13 & Bittuang & 5 & 1 & $\mathbf{6}$ \\
\hline 14 & Saluputti & 7 & 1 & $\mathbf{8}$ \\
\hline 15 & Malimbong Balepe & 8 & - & $\mathbf{8}$ \\
\hline 16 & Bonggakaradeng & 7 & - & $\mathbf{7}$ \\
\hline 17 & Rano & - & - & - \\
\hline 18 & Mappak & 1 & 2 & $\mathbf{3}$ \\
\hline 19 & Simbuang & 2 & - & $\mathbf{3}$ \\
\hline & Total & $\mathbf{4 6 9}$ & $\mathbf{6 7}$ & $\mathbf{5 3 6}$ \\
\hline
\end{tabular}

Sumber : Kantor Dinas Koperasi UMKM Tana Toraja, 2017

Sedangkan, sampel merupakan bagian dari jumlah dan karakteristik yang dimiliki oleh populasi. Bila populasi besar, dan peneliti tidak mungkin mempelajari semua yang ada pada populasi, karena keterbatasan waktu daya dan dana, maka peneliti dapat menggunakan sampel yang diambil dari populasi. Teknik pengambilan sampel yang peneliti gunakan adalah Probability Sampling yang memberikan peluang yang sama bagi setiap unsur anggota populasi untuk dipilih menjadi sampel.

Jumlah anggota sampel sering dinyatakan dengan ukuran sampel. Untuk mendapatkan jumlah sampel yang representatif, maka peneliti menentukan jumlah sampel dari populasi yang dikembangkan oleh Isaac dan Michael (dalam sugiyono, 2007) untuk tingkat kesalahan 5\%. Rumus untuk menghitung ukuran sampel dari populasi yang diketahui jumlahnya adalah sebagai berikut:

$$
S=\frac{\lambda^{2} \cdot N \cdot P \cdot Q}{d^{2}(N-1)+\lambda^{2} \cdot P \cdot Q}
$$

Keterangan: $\lambda^{2}$ dengan $\mathrm{dk}=1$, taraf kesalahan bisas $1 \%, 5 \%, 10 \% . \mathrm{P}=\mathrm{Q}=0,5 . \mathrm{D}=$ 0,05 dan $\mathrm{S}=$ jumlah sampel

Berdasarkan rumus tersebut dapat dihitung jumlah dari populasi pada Tabel penentuan jumlah sampel dari populasi tertentu dengan taraf kesalahan $1 \%, 5 \%$, dan 10\%. Untuk populasi Usaha Kecil (UK) sebanyak 469 untuk taraf kesalahan 5\% jumlah sampel $=198$. Untuk populasi Usaha Menengah (UM) sebanyak 67 untuk taraf kesalahan 5\% jumlah sampel $=55$. Untuk lebih jelasnya sampel tersebut, dapat dilihat pada Tabel 3 berikut ini:

Tabel 3. Jumlah Sampel Usaha Kecil dan Usaha Menengah

\begin{tabular}{llcccc}
\hline \multirow{2}{*}{ No } & \multirow{2}{*}{ Kecamatan } & \multicolumn{3}{c}{ Kentuk Usaha } \\
\cline { 3 - 6 } & & Pop. & \multicolumn{1}{c}{ Sampel } & Pop. & Sampel \\
\cline { 2 - 6 } 1 & Makale & 256 & $256 / 469 \times 198=\mathbf{1 0 8}$ & 49 & $49 / 67 \times 55=\mathbf{4 0}$ \\
\hline 2 & Makale Utara & 40 & $40 / 469 \times 198=\mathbf{1 7}$ & 5 & $5 / 67 \times 55=\mathbf{4}$ \\
\hline 3 & Makale Selatan & 6 & $6 / 469 \times 198=\mathbf{3}$ & 1 & $1 / 67 \times 55=\mathbf{1}$ \\
\hline 4 & Sangalla' & 13 & $13 / 469 \times 198=\mathbf{5}$ & - & - \\
\hline 5 & Sangalla' Utara & 12 & $12 / 469 \times 198=\mathbf{5}$ & - & - \\
\hline 6 & Sangalla' Selatan & 9 & $9 / 469 \times 198=\mathbf{4}$ & - & - \\
\hline
\end{tabular}




\begin{tabular}{llcccc}
\hline 7 & Mengkendek & 41 & $41 / 469 \times 198=\mathbf{1 7}$ & 6 & $6 / 67 \times 55=\mathbf{5}$ \\
\hline 8 & Gandang Batu & 28 & $28 / 469 \times 198=\mathbf{1 2}$ & - & - \\
\hline 9 & Rantetayo & 18 & $18 / 469 \times 198=\mathbf{7}$ & 2 & $2 / 67 \times 55=\mathbf{2}$ \\
\hline 10 & Kurra & 4 & $4 / 469 \times 198=\mathbf{2}$ & - & - \\
\hline 11 & Rembon & 12 & $12 / 469 \times 198=\mathbf{5}$ & - & - \\
\hline 12 & Masanda & - & - & - & - \\
\hline 13 & Bittuang & 5 & $5 / 469 \times 198=\mathbf{2}$ & 1 & $1 / 67 \times 55=\mathbf{1}$ \\
\hline 14 & Saluputti & 7 & $7 / 469 \times 198=\mathbf{3}$ & 1 & $1 / 67 \times 55=\mathbf{1}$ \\
\hline 15 & Malimbong & 8 & $8 / 469 \times 198=\mathbf{3}$ & - & - \\
\hline 16 & Bonggakaradeng & 7 & $7 / 469 \times 198=\mathbf{3}$ & - & - \\
\hline 17 & Rano & - & - & - & - \\
\hline 18 & Mappak & 1 & $1 / 469 \times 198=\mathbf{1}$ & 2 & $2 / 67 \times 55=\mathbf{1}$ \\
\hline 19 & Simbuang & 2 & $2 / 469 \times 198=\mathbf{1}$ & - & - \\
\hline \multicolumn{7}{c}{ Total } & $\mathbf{4 6 9}$ & $\mathbf{1 9 8}$ & $\mathbf{6 7}$ & $\mathbf{5 5}$ \\
\hline
\end{tabular}

Sumber : Data setelah diolah.

Hasil analisis deskriptif data penelitian dapat digunakan untuk memperdalam dan memperkaya pembahasan melalui gambaran atas tanggapan responden terhadap setiap indikator variabel yang diteliti. Untuk memudahkan menginterpretasikan variabel yang sedang diteliti, maka dilakukan kategorisasi terhadap setiap skor tanggapan responden.

\section{HASIL PENELITIAN}

\section{Penerapan Kewirausahaan Korporasi UKM di Kabupaten Tana Toraja}

Para pelaku UKM sebaiknya memiliki kemampuan kewirausahaan korporasi dengan tiga dimensi, yaitu (1) proaktif, (2) inovasi dan (3) keberanian mengambil resiko yang secara keseluruhan merupakan motivasi dan karakteristik yang sangat mendasar dalam menjalankan usaha untuk mencapai tujuan berbisnis secara baik dan benar.

Kemampuan kewirausahaan korporasi pelaku UKM di Kabupaten Tana Toraja dapat dilihat pada jawaban responden terhadap pernyataan-pernyataan yang ada pada kuesioner yang mencakup 3 (tiga) dimensi. Kewirausahaan korporasi diukur menggunakan 3 (tiga) dimensi dan dioperasionalisasikan ke dalam 19 butir pernyataan. Berikut rekapitulasi tanggapan responden terhadap setiap butir pernyataan pada masingmasing dimensi, sebagai berikut:

\section{Pelaku UKM yang Berinovasi}

Dimensi inovasi diukur menggunakan 5 buah alternatif jawaban menyangkut usaha menciptakan ide baru yang dapat digunakan oleh UKM, usaha menciptakan kreatifitas yang dapat digunakan oleh UKM untuk mencari peluang baru, serta memperkenalkan banyak produk baru ke pasar. Berikut ini rekapitulasi skor tanggapan responden tentang inovasi pada tabel 4 berikut ini

Tabel 4 Rekapitulasi Skor Tanggapan Responden Tentang Inovasi

\begin{tabular}{|c|c|c|c|c|c|c|c|}
\hline \multirow{2}{*}{ Item Pernyataan } & & \multicolumn{5}{|c|}{ Skor Jawaban Responden } & \multirow{2}{*}{$-\Sigma$ Skor } \\
\hline & & 5 & 4 & 3 & 2 & 1 & \\
\hline \multirow{2}{*}{$\begin{array}{l}\text { Dengan menciptakan ide baru akan } \\
\text { membuka peluang baru }\end{array}$} & $\mathrm{F}$ & 119 & 91 & 42 & 1 & 0 & \multirow[t]{2}{*}{1087} \\
\hline & $\%$ & 47.04 & 35.97 & 16.60 & 0.39 & 0.00 & \\
\hline \multirow{2}{*}{$\begin{array}{l}\text { Kreativitas akan membuka peluang } \\
\text { baru }\end{array}$} & $\mathrm{F}$ & 68 & 85 & 70 & 30 & 0 & \multirow[t]{2}{*}{920} \\
\hline & $\%$ & 26.87 & 35.59 & 26.63 & 11.85 & 0.00 & \\
\hline Memperkenalkan produk baru ke & $\mathrm{F}$ & 77 & 97 & 52 & 25 & 2 & 981 \\
\hline
\end{tabular}




\begin{tabular}{|c|c|c|c|c|c|c|c|}
\hline \multirow{3}{*}{$\begin{array}{l}\text { Item Pernyataan } \\
\text { pasar akan menguntungkan }\end{array}$} & \multicolumn{6}{|c|}{ Skor Jawaban Responden } & \multirow{2}{*}{$\Sigma$ Skor } \\
\hline & & 5 & 4 & 3 & 2 & 1 & \\
\hline & $\%$ & 30.44 & 38.34 & 20.55 & 9.88 & 0.79 & \\
\hline \multirow{2}{*}{$\begin{array}{l}\text { Produk yang dihasilkan selalu } \\
\text { mengikuti selera atau keinginan pasar }\end{array}$} & $\mathrm{F}$ & 87 & 81 & 50 & 35 & 0 & \multirow[t]{2}{*}{979} \\
\hline & $\%$ & 34.39 & 32.02 & 19.76 & 13.83 & 0.00 & \\
\hline \multirow{2}{*}{$\begin{array}{l}\text { Produk yang dihasilkan mempunyai } \\
\text { keunggulan dibanding pesaing }\end{array}$} & $\mathrm{F}$ & 48 & 46 & 76 & 82 & 1 & \multirow[t]{2}{*}{817} \\
\hline & $\%$ & 18.97 & 18.18 & 30.04 & 32.41 & 0.40 & \\
\hline \multirow{2}{*}{ Total } & $\mathbf{F}$ & 399 & 400 & 290 & 173 & 3 & \multirow[t]{2}{*}{4784} \\
\hline & $\%$ & 31.58 & 31.72 & 22.92 & 13.76 & 0.24 & \\
\hline
\end{tabular}

Berdasarkan Tabel 4 di atas rekapitulasi skor tanggapan responden tentang inovasi, menunjukkan bahwa skor tertinggi adalah menciptakan ide baru akan membuka peluang baru. Hal tersebut berarti bahwa pelaku UKM di Kabupaten Tana Toraja yakin bahwa dengan menciptakan ide baru akan membuka peluang baru. Sebaliknya skor terendah adalah produk yang dihasilkan mempunyai keunggulan yang lebih dibanding pesaing. Inovasi tidak selalu berarti harus mengeluarkan produk baru yang inovatif. Inovasi juga tidak berarti harga yang harus mahal dan proses yang mahal, inovasi juga berarti menjalankan bisnis dengan cara yang baru, misalnya dalam hal pelayanan pelanggan yang simpatik penuh senyum, ataupun inovasi dalam hal menciptakan model wirausaha yang baik dan bertanggung jawab.

Menjalin hubungan yang serasi dan seimbang dengan pelanggan, maka berarti menciptakan pelaku UKM inovator, motivator dan pada akhirnya menjadi unggul dalam hal pelayanan lebih kepada pelanggan. Selain inovasi produk, UKM bisa pula melakukan inovasi dalam bentuk pelayanan. Jika pelaku UKM unggul dalam pelayanan yang prima dan seimbang, pelanggan akan cenderung menjadi lebih setia, percaya, kepada proses bisnis pelaku UKM.

Untuk menetapkan tingkat kategori skor tanggapan responden mengenai inovasi, maka dilakukan kategorisasi terhadap jumlah skor tanggapan responden. Pada dimensi inovasi dengan jumlah item pernyataan 5 buah dan jumlah responden 253 orang, maka rentang skor setiap kategori ditentukan sebagai berikut:

Skor maksimum $\quad=253 \times 5 \times 5=6325$

Skor minimum $\quad=253 \times 5 \times 1=1265$

Rentang skor $\quad=6325-1265=5060$

Panjang kelas $\quad=5060: 5=1012$

Hasil jawaban responden terhadap lima butir pernyataan yang terdapat pada Tabel 5 dikategorikan kedalam kriteria Sangat Baik, Baik, Cukup Baik, Kurang Baik dan Tidak Baik. Dengan panjang kelas interval untuk setiap kategori sebesar 1012, maka interval skor untuk setiap kategori ditetapkan seperti pada gambar 1 yaitu Garis Kontinum Kategorisasi Dimensi Inovasi sebagai berikut.

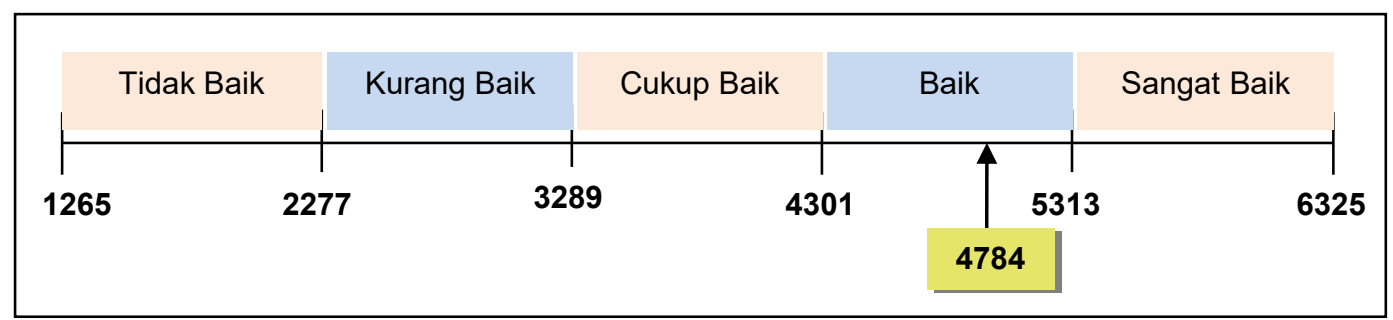


Berdasarkan hasil pengkategorian tersebut, jumlah skor tanggapan responden atas lima buah pernyataan sebesar 4784, menunjukkan bahwa tingkat tanggapan responden terhadap lima butir pernyataan yang diajukan mengenai inovasi termasuk dalam kategori baik. Meskipun berada pada kategori baik, namun keunggulan produk dibanding pesaing masih perlu mendapat perhatian yang serius.

Hasil pengkategorian tersebut di atas, mencerminkan bahwa inovasi produk yang dilakukan oleh pelaku UKM di Kabupaten Tana Toraja masih lemah, yang berakibat pada kurang berkualitasnya produk yang dihasilkan. Kemampuan bersaing dengan lemahnya inovasi yang dimiliki akan mengurangi kemampuan pengusaha kecil menengah untuk memecahkan masalah yang dihadapi. Inovasi merupakan kemampuan yang dimiliki oleh pelaku UKM untuk mengembangkan sesuatu yang belum dilakukan oleh pelaku lain. Apabila kemampuan inovasi yang dimiliki belum tepat, maka produk yang dihasilkan cenderung sama antara yang satu dengan yang lain sehingga mengurangi daya saing.

\section{Pelaku UKM yang Proaktif}

Proaktif berkaitan dengan mencari peluang baru, mencari gagasan baru, menciptakan perubahan, lebih agresif dari pada pesaing, dan kemampuan memperkirakan dan menyikapi perubahan pasar secara tepat dan cermat. Dimensi proakif diukur menggunakan 5 buah pernyataan menyangkut usaha mencari dan memanfaatkan peluang baru, usaha mencari gagasan baru serta menciptakan perubahan.

Berikut ini akan digambarkan rekapitulasi skor tanggapan responden terhadap dimensi proaktif seperti pada tabel 5 berikut ini:

Tabel 5 Rekapitulasi Skor Tanggapan Responden Tentang Proaktif

\begin{tabular}{|c|c|c|c|c|c|c|c|}
\hline \multirow{2}{*}{ Item Pernyataan } & \multicolumn{6}{|c|}{ Skor Jawaban Responden } & \multirow{2}{*}{$-\Sigma$ Skor } \\
\hline & & 5 & 4 & 3 & 2 & 1 & \\
\hline \multirow{2}{*}{ usaha mencari peluang baru } & $\mathrm{F}$ & 42 & 110 & 61 & 40 & 0 & \multirow[t]{2}{*}{913} \\
\hline & $\%$ & 16.60 & 43.48 & 24.11 & 15.81 & 0.00 & \\
\hline \multirow{2}{*}{ usaha mencari gagasan baru } & $\mathrm{F}$ & 43 & 106 & 64 & 40 & 0 & \multirow[t]{2}{*}{911} \\
\hline & $\%$ & 16.99 & 41.90 & 25.30 & 15.81 & 0.00 & \\
\hline \multirow{2}{*}{$\begin{array}{l}\text { usaha menciptakan } \\
\text { perubahan }\end{array}$} & $\mathrm{F}$ & 73 & 112 & 62 & 6 & 0 & \multirow[t]{2}{*}{1011} \\
\hline & $\%$ & 28.85 & 44.27 & 24.51 & 2.37 & 0.00 & \\
\hline \multirow{3}{*}{$\begin{array}{l}\text { usaha lebih agresif } \\
\text { dibandingkan dengan } \\
\text { pesaing }\end{array}$} & $\mathrm{F}$ & 57 & 87 & 74 & 33 & 2 & \multirow[t]{3}{*}{923} \\
\hline & $\%$ & & & & & & \\
\hline & & 22.53 & 34.39 & 29.25 & 13.04 & 0.79 & \\
\hline \multirow{2}{*}{$\begin{array}{l}\text { usaha memperhatikan } \\
\text { perubahan pasar }\end{array}$} & $\mathrm{F}$ & 83 & 112 & 49 & 8 & 1 & \multirow[t]{2}{*}{1031} \\
\hline & $\%$ & 32.81 & 44.27 & 19.37 & 3.16 & 0.40 & \\
\hline \multirow{2}{*}{ usaha memperkirakan pasar } & $\mathrm{F}$ & 83 & 113 & 47 & 10 & 0 & \multirow[t]{2}{*}{1028} \\
\hline & $\%$ & 32,81 & 44.66 & 18.58 & 3,95 & 0.00 & \\
\hline \multirow[b]{2}{*}{ otal } & $\mathbf{F}$ & 381 & 640 & 357 & 137 & 3 & \multirow{2}{*}{5817} \\
\hline & & 25.10 & 42.16 & 23.52 & 9.26 & 0.20 & \\
\hline
\end{tabular}

Berdasarkan Tabel 5 terlihat bahwa skor tertinggi untuk dimensi proaktif yaitu perlu usaha memperkirakan perubahan pasar, usaha menciptakan perubahan, mencari gagasan baru dan mencari peluang baru. Oleh sebab itu dapat dikatakan bahwa pelaku UKM di Kabupaten Tana Toraja mempunyai sikap yang dapat memperkirakan 
perubahan pasar, mampu mencari gagasan baru dan peluang baru dan mampu mengantisipasi setiap perubahan lingkungan usaha. Berdasarkan hasil pengkategorian dimensi proaktif, jumlah skor tanggapan responden atas kelima butir pernyataan sebesar 5817, menunjukkan bahwa tingkat tanggapan responden terhadap kelima buah pernyataan yang diajukan mengenai proaktif termasuk dalam kategori baik.

Selanjutnya untuk menetapkan tingkat kategori skor tanggapan responden mengenai dimensi proaktif, maka dilakukan kategorisasi terhadap jumlah skor tanggapan responden. Pada dimensi proaktif, dengan jumlah item pernyataan 5 buah dan jumlah responden 253 orang, maka rentang skor setiap kategori ditentukan sebagai berikut:

$$
\begin{array}{ll}
\text { Skor maksimum } & =253 \times 6 \times 5=7590 \\
\text { Skor minimum } & =253 \times 6 \times 1=1518 \\
\text { Rentang skor } & =7590-1518=6072 \\
\text { Panjang kelas } & =6072: 5=1214.4
\end{array}
$$

Hasil jawaban responden terhadap kelima buah pernyataan yang terdapat pada tabel 5 dikategorikan kedalam kriteria Sangat Baik, Baik, Cukup Baik, Kurang Baik dan Tidak Baik. Dengan panjang kelas interval untuk setiap kategori sebesar 1214.4, maka interval skor untuk setiap kategori ditetapkan gambar berikut tentang Garis Kontinum Kategorisasi Dimensi Proaktif sebagai berikut:

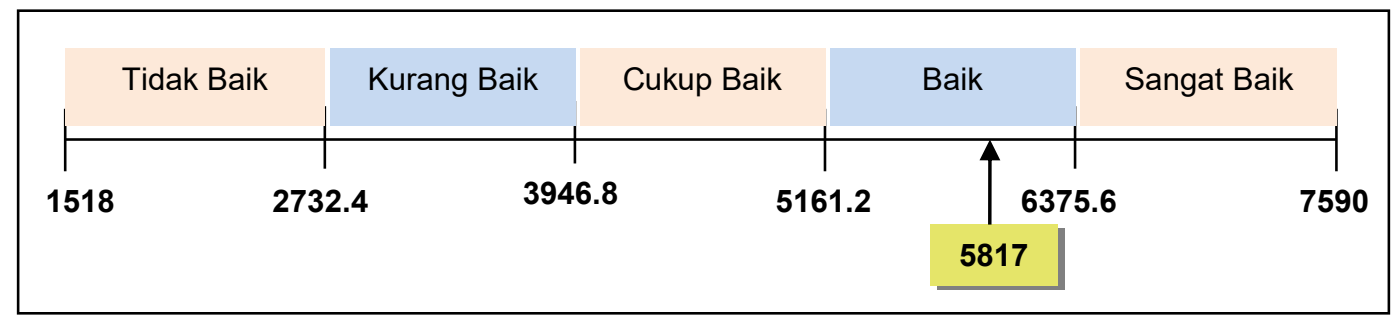

Berdasarkan hasil pengkategorian tersebut, jumlah skor tanggapan responden atas kelima buah pernyataan sebesar 5817, menunjukkan bahwa tingkat tanggapan responden terhadap kelima buah pernyataan yang diajukan mengenai proaktif termasuk dalam kategori baik. Meskipun berada pada kriteria baik, namun masih lemah pada memperkirakan perubahan pasar. Data ini mencerminkan bahwa sebagian besar UKM di Kabupaten Tana Toraja sudah proaktif secara maksimal dalam mencari gagasan baru untuk memanfaatkan dan menciptakan peluang baru. Adapun usaha dari Dinas Perindustrian, Perdagangan, Koperasi dan UMKM Kabupaten Tana Toraja lebih proaktif untuk memanfaatkan sumber pendanaan dari lembaga perbankan yang menyalurkan bantuan modal untuk UKM.

\section{Keberanian Menanggung Resiko}

Dimensi keberanian menanggung resiko berkaitan dengan keberanian pelaku UKM untuk memulai menjalankan usaha dengan menggunakan peluang seoptimal dan semampu mungkin sesuai dengan potensi dan kompetensi yang dimiliki, dengan kesediaan menanggung akibat dari kegagalan bila ternyata usaha yang dijalankan tidak atau belum mencapai keuntungan diharapkan. Keberanian menanggung resiko tidak hanya dibutuhkan pada saat memulai usaha, tetapi juga untuk menumbuhkembangkan usaha tersebut. Sifat pelaku UKM dalam menghadapi resiko dapat digolongkan kedalam 3 (tiga) macam sifat menghadapi atau menanggung resiko yaitu: pelaku yang suka 
dengan resiko tinggi, pelaku yang memiliki sifat suka mengambil resiko sedang, dan pelaku yang memiliki sifat tidak pernah mundur walaupun ada resiko usaha yang akan ditanggung.

Dimensi keberanian menanggung resiko diukur menggunakan 8 (delapan) buah pernyataan menyangkut komitmen terhadap pengelolaan usaha dalam memanfaatkan peluang terhadap sumber daya yang ada, perhatian lebih pada pekerjaan yang berisiko tinggi serta strategi dan sasaran jangka panjang usaha. Berikut ini akan digambarkan rekapitulasi skor tanggapan responden terhadap keberanian menanggung resiko pada tabel 6 berikut ini:

Tabel 6 Rekapitulasi Skor Tanggapan Responden Tentang

Keberanian Menanggung Resiko

\begin{tabular}{|c|c|c|c|c|c|c|c|}
\hline \multirow{2}{*}{ Item Pernyataan } & \multicolumn{6}{|c|}{ Skor Jawaban Responden } & \multirow{2}{*}{$-\Sigma$ Skor } \\
\hline & & 5 & 4 & 3 & 2 & 1 & \\
\hline \multirow{2}{*}{$\begin{array}{l}\text { Perlu mempunyai komitmen } \\
\text { memanfaatkan peluang yang ada }\end{array}$} & $\mathrm{F}$ & 68 & 127 & 53 & 5 & 0 & \multirow[t]{2}{*}{1017} \\
\hline & $\%$ & 26.88 & 50.20 & 20.95 & 1.97 & 0.00 & \\
\hline \multirow{2}{*}{$\begin{array}{l}\text { Menunjukkan perhatian lebih pada } \\
\text { pekerjaan yang berisiko tinggi }\end{array}$} & $\mathrm{F}$ & 83 & 115 & 51 & 4 & 0 & \multirow[t]{2}{*}{1036} \\
\hline & $\%$ & 32.81 & 45.45 & 20.16 & 1.58 & 0.00 & \\
\hline \multirow{2}{*}{ Siap menghadapi kegagalan } & $\mathrm{F}$ & 100 & 113 & 38 & 2 & 0 & \multirow[t]{2}{*}{1070} \\
\hline & $\%$ & 39.52 & 44.66 & 15.02 & 0.79 & 0.00 & \\
\hline \multirow{2}{*}{$\begin{array}{l}\text { Siap menghadapi persaingan yang } \\
\text { lebih ketat }\end{array}$} & $\mathrm{F}$ & 85 & 118 & 40 & 10 & 0 & \multirow[t]{2}{*}{1037} \\
\hline & $\%$ & 33.60 & 46.64 & 15.81 & 3.95 & 0,00 & \\
\hline \multirow{2}{*}{$\begin{array}{l}\text { Siap menghadapi perkembangan } \\
\text { teknologi }\end{array}$} & $\mathrm{F}$ & 69 & 151 & 30 & 3 & 0 & \multirow[t]{2}{*}{1045} \\
\hline & $\%$ & 27.27 & 59.68 & 11.86 & 1.19 & 0.00 & \\
\hline \multirow{2}{*}{ Siap menghadapi pasar global } & $\mathrm{F}$ & 55 & 168 & 27 & 3 & 0 & \multirow[t]{2}{*}{1034} \\
\hline & $\%$ & 21.74 & 66.40 & 10.67 & 1.19 & 0.00 & \\
\hline \multirow{2}{*}{$\begin{array}{l}\text { Perlu bertujuan pada strategi } \\
\text { perusahaan }\end{array}$} & $\mathrm{F}$ & 65 & 117 & 62 & 9 & 0 & \multirow[t]{2}{*}{997} \\
\hline & $\%$ & 25.69 & 46.25 & 24.51 & 3.56 & 0.00 & \\
\hline \multirow{2}{*}{$\begin{array}{l}\text { Perlu bertujuan pada sasaran jangka } \\
\text { panjang perusahaan }\end{array}$} & $\mathrm{F}$ & 78 & 108 & 67 & 0 & 0 & \multirow[t]{2}{*}{1023} \\
\hline & $\%$ & 30.83 & 42.69 & 26.48 & 0.00 & 0.00 & \\
\hline \multirow{2}{*}{ Total } & $\mathbf{F}$ & 106 & 909 & 368 & 36 & $\mathbf{0}$ & \multirow[t]{2}{*}{8259} \\
\hline & $\%$ & 7.47 & 64.06 & 25.93 & 2.54 & 0.00 & \\
\hline
\end{tabular}

Berdasarkan tabel 7 dapat dilihat bahwa sebagian besar responden merasa yakin mempunyai komitmen memanfaatkan peluang yang ada, menunjukkan perhatian lebih pada pekerjaan yang berisiko tinggi, siap menghadapi kegagalan yang lebih ketat dan siap menghadapi persaingan yang lebih ketat, dan hanya sebagian kecil responden yang merasa kurang yakin. Skor tertinggi dari item pernyataan ini adalah bahwa pelaku UKM di Kabupaten Tana Toraja siap menghadapi kegagalan, hal tersebut menunjukkan bahwa komitmen berusaha selalu siap apapun terjadi harus mendapat perhatian serius, walaupun itu kegagalan dalam mencapai tujuan.

Skor tertinggi untuk item keberanian menanggung resiko adalah siap menghadapi kegagalan, kemudian diikuti oleh sikap mengikuti perkembangan teknologi lalu diikuti oleh siap menghadapi persaingan yang lebih ketat dan memanfaatkan peluang yang ada, yang kurang adalah menerapkan strategi perusahaan. Selanjutnya, untuk menetapkan tingkat kategori skor tanggapan responden mengenai keberanian mengambil risiko, dilakukan kategorisasi terhadap jumlah skor tanggapan responden. Pada dimensi keberanian mengambil risiko, dengan jumlah item pernyataan 8 buah dan 
jumlah responden 253 orang, maka rentang skor setiap kategori ditentukan sebagai berikut:

$\begin{array}{ll}\text { Skor maksimum } & =253 \times 8 \times 5=10120 \\ \text { Skor minimum } & =253 \times 8 \times 1=2024 \\ \text { Rentang skor } & =10120-2024=8096 \\ \text { Panjang kelas } & =8096: 5=1619.2\end{array}$

Hasil jawaban responden terhadap kedelapan buah pernyataan yang terdapat pada tabel 7 dikategorikan kedalam kriteria Sangat Baik, Baik, Cukup Baik, Kurang Baik dan Tidak Baik. Dengan panjang kelas interval untuk setiap kategori sebesar 1619.2 maka interval skor untuk setiap kategori dapat dilihat pada gambar 3 garis kontinum kategorisasi dimensi keberanian menanggung resiko ditetapkan sebagai berikut:

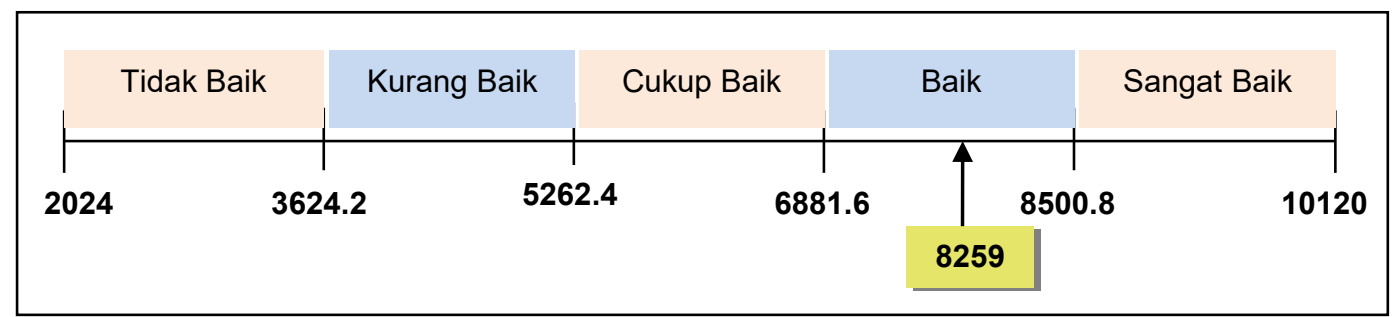

Berdasarkan hasil pengkategorian tersebut, jumlah skor tanggapan responden atas kedelapan butir pernyataan sebesar 8259, menunjukkan bahwa tingkat tanggapan responden terhadap kedelapan butir pernyataan yang diajukan mengenai keberanian mengambil risiko termasuk dalam kategori baik. Meskipun berada pada kriteria baik, namun belum siap menggunakan strategi perusahaan yang akan berpengaruh pada keberanian untuk menanggung risiko.

Data ini mencerminkan bahwa sebagian besar UKM di Kabupaten Tana Toraja sudah berani menanggung risiko dalam menjalankan usahanya, oleh karena itu perlunya kesiapan mental dalam menghadapi pesaing dari luar, pasar global dan kemajuan teknologi. Pada umumnya pelaku UKM yang berhasil memiliki kemampuan untuk memilih risiko yang tinggi maupun sedang, dimana ketika mengambil keputusan memerlukan pertimbangan yang matang, hal ini menunjukkan bahwa kegagalan dalam berbisnis tidak perlu ditakuti, karena itu sudah resiko, oleh sebab itu perlu menerapkan strategi bisnis jangka pendek dan jangka panjang.

Untuk mengetahui sejauhmana kewirausahaan korporasi yang dilakukan oleh UKM di Kabupaten Tana Toraja secara keseluruhan, maka penulis melakukan kategorisasi terhadap akumulasi skor jawaban responden atas ketiga dimensi yang diajukan mengenai kewirausahaan korporasi. Berikut disajikan data akumulasi jawaban responden atas ketiga dimensi pada variabel kewirausahaan korporasi pada tabel 8 berikut ini: 
Tabel 8 Rekapitulasi Skor Tanggapan Responden Pada Variabel Kewirausaan Korporasi

\begin{tabular}{|c|c|c|c|c|c|c|c|}
\hline \multirow{2}{*}{ Dimensi } & \multicolumn{6}{|c|}{ Skor Jawaban Responden } & \multirow{2}{*}{$-\Sigma$ Skor } \\
\hline & & 5 & 4 & 3 & 2 & 1 & \\
\hline \multirow{2}{*}{ Inovasi } & $\mathrm{F}$ & 399 & 400 & 290 & 173 & 3 & 4784 \\
\hline & $\%$ & 31.58 & 31.72 & 22.92 & 13.76 & 0.24 & \\
\hline \multirow{2}{*}{ Proaktif } & $\mathrm{F}$ & 381 & 640 & 357 & 137 & 3 & 5817 \\
\hline & $\%$ & 25.10 & 42.16 & 23.52 & 9.26 & 0.20 & \\
\hline \multirow{2}{*}{ Keberanian Mengambil Risiko } & $\mathrm{F}$ & 106 & 909 & 368 & 36 & 0 & 8259 \\
\hline & $\%$ & 7.47 & 64.06 & 25.93 & 2.54 & 0.00 & \\
\hline & $\mathbf{F}$ & 886 & 1949 & 1015 & 346 & 6 & 18860 \\
\hline Total & $\%$ & 21.09 & 46.38 & 24.16 & 8.23 & 0.14 & \\
\hline
\end{tabular}

Berdasarkan tabel 8 skor tertinggi untuk jawaban responden terhadap dimensi kewirausahaan korporasi adalah dimensi keberanian mengambil resiko, hal itu menunjukkan bahwa para pelaku UKM di Kabupaten Tana Toraja sudah siap menghadapi resiko dalam berbisnis. Hal ini dipahami karena pada umumnya pelaku UKM tersebut adalah orang Toraja sendiri, yang mempunyai motivasi untuk bertahan dan mencari penghidupan yang lebih baik di kampung kelahiran sendiri.

Selanjutnya untuk menguji hipotesis deskriptif mengenai kewirausahaan korporasi UKM di Kabupaten Tana Toraja, dilakukan pengujian terhadap median jumlah skor tanggapan responden. Median yang dihipotesiskan dihitung menggunakan rumus sebagai berikut:

Skor maksimum $\quad=253 \times 19 \times 5=24035$

Skor minimum $\quad=253 \times 19 \times 1=4807$

Median $\quad=(24035+4807): 2=14421$

Jadi hipotesis deskriptif yang digunakan untuk menguji kewirausahaan korporasi UKM di Kabupaten Tana Toraja diformulasikan sebagai berikut.

Ho. Median $\leq 14421$ : Artinya UKM di Kabupaten Tana Toraja belum menerapkan kewirausahaan korporasi

H1. Median $>14421$ : Artinya UKM di Kabupaten Tana Toraja sudah menerapkan kewirausahaan korporasi

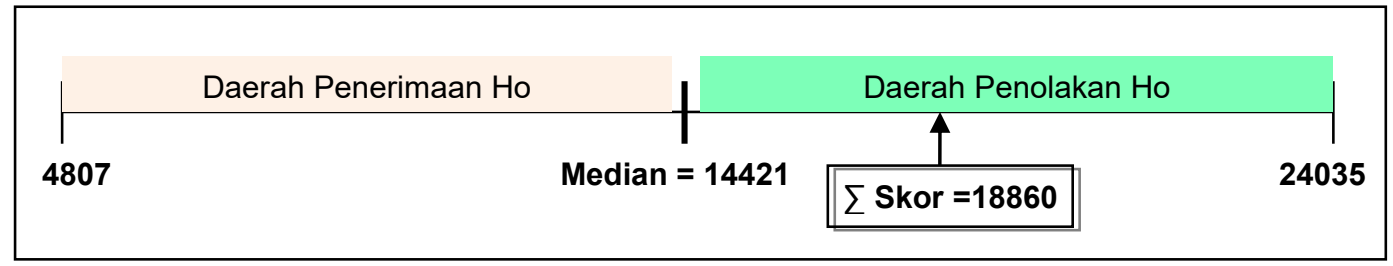

Jumlah skor tanggapan responden atas 19 (kesembilan belas) buah pernyataan pada variabel kewirausahaan korporasi sebesar $\mathbf{1 8 8 6 0}$ dan berada didaerah penolakan Ho yang menunjukkan bahwa UKM di Kabupaten Tana Toraja sudah menerapkan kewirausahaan korporasi, namum belum maksimal berinovasi, masih belum maksimal berani menanggung risiko, dan sikap proaktif sudah memadai. Data tersebut juga menunjukkan bahwa sebagian besar UKM di Kabupaten Tana Toraja belum sepenuhnya 
memiliki kewirausahan korporasi dalam menjalankan usahanya dan belum dikelola dengan prinsip-prinsip berwirausaha yang baik, yang memungkinkan pelaku tetap kuat senantiasa bersikap proaktif menghadapi dinamika bisnis, tetapi juga berpotensi untuk bertumbuh dan berkembang secara konsisten

\section{PEMBAHASAN}

Berdasarkan hasil analisis data deskriptif pada dimensi kewirausahaan korporasi diperoleh tanggapan responden bahwa sebagian besar pelaku UKM di Kabupaten Tana Toraja meyakini bahwa dengan menciptakan ide baru akan membuka peluang baru, namun kemampuan kreativitas pelaku UKM masih rendah karena pengetahuan dan keterampilan juga masih rendah, oleh sebab itu sikap kreativitas dan inovatif masih perlu mendapat perhatian khusus, melalui pelatihan secara berkala.

Skor tertinggi tanggapan responden terhadap dimensi kewirausahaan korporasi adalah dimensi proaktif, hal itu menunjukkan bahwa para pelaku UKM di Kabupaten Tana Toraja selalu aktif dalam mengikuti perkembangan dan dinamika bisnis yang sangat dinamis. Hal ini dipahami karena pada umumnya pelaku UKM tersebut adalah orang Toraja sendiri, yang mempunyai motivasi untuk bertahan dan mencari penghidupan yang lebih baik di kampung kelahiran sendiri.

Hasil penelitian Barret dan Weinstein (2000) menyatakan bahwa kewirausahaan korporasi berhubungan sangat kuat dengan kinerja bisnis. Berdasarkan fakta semakin besar perusahaan maka semakin besar hubungannya dengan kinerja perusahaan. Hal ini menunjukkan bahwa variabel kewirausahaan korporasi belum cocok diterapkan pada usaha kecil, ini terlihat pada hasil penelitian yang mana pengaruh kewirausahaan korporasi terhadap orientasi pembelajaran dan kinerja bisnis sangat kecil.

\section{KESIMPULAN}

Hasil analisis deskriptif membuktikan bahwa pelaku UKM di Kabupaten Tana Toraja sudah menerapkan konsep kewirausahaan korporasi dengan memadai. Penerapan konsep kewirausahaan korporasi sudah dilakukan namun belum maksimal, masih lemahnya inovasi sehingga rendahnya kualitas produk dan kesediaan menanggung resiko juga rendah karena belum menerapkan strategi perusahaan untuk mencapai tujuan, tetapi pada sikap proaktif yang sudah lebih baik, karena memperhatikan perubahan pasar.

\section{DAFTAR PUSTAKA}

Barret, H, Balloun \& Weinstein (2000). The Effect of market Orientation and Organizational Flexibility on Corporate Entrepreneurship; Theory and Practice, Journal of Marketing, vol.23 (1).

Bakhtiar, B. (2017). Manajemen Keuangan Daerah (Pengelolaan Keuangan daerah Berbasis Ekonomis, Efesiensi \& Efektifitas). Makassar: PT. Umi Toha

Drucker, Peter F (2003). Inovasi dan Kewiraswastaan: praktek dan dasar-dasar. (Terjemahan: Innovation and Enterpreneurship, oleh: Rusjdi Naib). Jakarta: Penerbit Erlangga.

Hisrich D. Robert, Peters.P Michael, A. Shepherd A. Dean (2008). Entrepreneurship Kewirausahaan. Edisi 7, Penerjemah Chriswan Sungkono dan Diana Angelica, Penerbit Salemba Empat.

Hills, G., \& Shrader, R. C. (1998). Successful entrepreneurs' insights into opportunity recognition. In P. D. Reynolds (Ed.), Frontiers of entrepreneurship research. Wellsley, MA: Babson College. 
Lumpkin, G. \& Dess, G (2003). Linking Two Dimensions of Entrepreneurial Orientation to Firm Performance: The Moderating Role of Environment and Industry Life Cycle. Journal of Business Venturing, Vol.16.

Maredith G. Geoffey. 1996. Kewirausahaan: Teori dan Praktik. Jakarta: Penerbit Pustaka Binaman Presindo

Sugiyono.2007. Metode Penelitian Bisnis. Bandung: Penerbit Alfabeta

Tenrigau, A. M., dkk. 2018. Manajemen Sebuah Pengantar. Palopo: Andi Djemma Press

Zimmerer,W.Thomas, Norman M. Scarborough. 1996. Enterpreneurship and The New Venture Formation. New Jersey: Prentice Hall International Inc. 